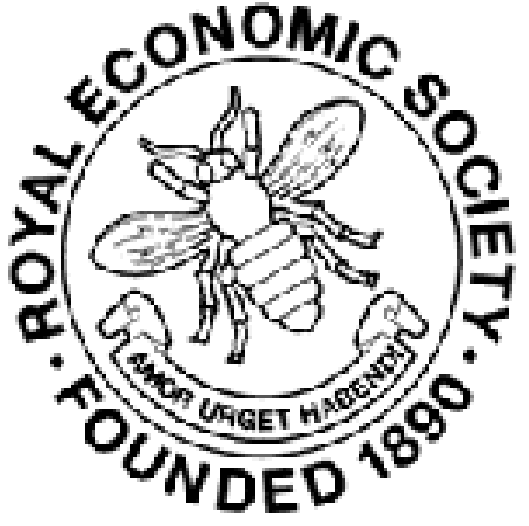

Free Trade and Protection

Author(s): L. L. Price

Source: The Economic Journal, Vol. 12, No. 47 (Sep., 1902), pp. 305-319

Published by: Wiley on behalf of the Royal Economic Society

Stable URL: http://www.jstor.org/stable/2956894

Accessed: 27-06-2016 02:49 UTC

Your use of the JSTOR archive indicates your acceptance of the Terms \& Conditions of Use, available at

http://about.jstor.org/terms

JSTOR is a not-for-profit service that helps scholars, researchers, and students discover, use, and build upon a wide range of content in a trusted digital archive. We use information technology and tools to increase productivity and facilitate new forms of scholarship. For more information about JSTOR, please contact support@jstor.org.

Royal Economic Society, Wiley are collaborating with JSTOR to digitize, preserve and extend access to The Economic Journal 


\section{THE ECONOMIC JOURNAL}

SEPTEMBER, 1902

\section{FREE TRADE AND PROTECTION}

A combination of circumstances seems now to be conspiring to force again to the front in this country the question of Free Trade and Protection. The inclusion of a small duty upon corn among the taxes proposed by the Chancellor of the Exchequer for 1902 has raised a larger discussion than that opened by the measure itself. The establishment of closer relations between England and her Colonies, which has been the acknowledged object of the conference of the Colonial Premiers assembled for the Coronation, has been known to include the suggestion of a fiscal preference for Imperial trade. It has become impossible during the last few months to study those periodical reviews, which make it their business to reflect, if it is not their ambition to direct, the currents of opinion, without being impressed by the prominence given to articles urging a revision, less or more drastic, of our Free Trade policy. For good or for evil the economist must admit that a brisk controversy is stirring on the question; and he will naturally ask what is the attitude which he ought to take.

$\mathrm{He}$ is confronted by no lack of counsellors. On the one hand he is assured that it is his imperative duty to denounce any departure from our present fiscal system as economic heresy of the most ignorant and mischievous kind. $\mathrm{He}$ is reminded that the repeal of the Corn Laws, the disappearance of the Navigation Laws, and the removal of the cumbrous and complicated tariff, of which this legislation formed part, supply a most signal instance of the successful application of economic

No. 47.- vol. XII. 
theory to political practice; and he is asked if he is going to be a traitor to teaching, which Pitt learnt from Adam Smith, and to lend his aid in undoing the work of beneficial reform, which Huskisson initiated, Peel developed and Gladstone completed. $\mathrm{He}$ is adjured to avoid the reproach of giving any countenance to the errors and blunders which some modern protectionists have inherited from some adherents of the old Mercantile creed; and, if he himself will not remain among the very elect, he is warned not to soil his purity by contact with the damned. For Free Trade, he is told, is economic orthodoxy, and any departure from its faith or its practice is economic heresy ; and a "whiff" of Protection has been likened by a distinguished prelate in the columns of a leading newspaper to a "whiff" of poisonous sewer gas.

On the other hand, a body of public opinion, which is equally vigorous, and not less influential, has embraced this fresh opportunity of pronouncing that economic opinion may safely be set aside as obsolete or irrelevant. It belongs to an antiquated past; and, just as the anticipations entertained by Cobden and Bright that the civilised world would follow the example of England have been falsified by the revival or extension of Protectionist policy, so the reasoning, by which they supported their opinions, is inapplicable to present conditions. A change, which is needed in the interests of the Empire, is not to be burked by any appeal to old-fashioned discredited doctrine. The reasonings of the economist may possibly be true of the unreal world of abstraction in which he thinks and moves; they are useless or mischievous guides in those real affairs of actual life with which practical statesmen have to deal. The question does not belong to the domain of pure economics; it is one which a common-sense knowledge of men and of things must attack undisturbed by bias or timidity. If "opportunities of closer union" with the Colonies, involving some departure from Free Trade, are to be condemned because they conflict with the teaching of economists, then Eeonomies must be gently, but firmly, reminded that it has forfeited its claim to be heard. "Economic pedantry" cannot be allowed to endanger the future of England; "old shibboleths" must be relegated to the harmless oblivion which they have earned.

The economist who does not agree with either of these views, so noisily asserted and so boldly affirmed, may be allowed to state his opinions, without being charged with ignorant folly or obsolete prejudice, in the quiet corner, removed from the turmoil 
of the world, which the society of his colleagues provides. And he may still hope that before the question of Free Trade and Protection is finally decided afresh by British and Colonial men of affairs some opportunity may yet be secured for sober and honest attention to the counsel of Economics, even if it fails to satisfy fully the clamorous demands of "either party in the public discussion. For it now hardly seems likely that the mother country or the Colonies will be prepared. without prolonged consideration to adopt a fiscal policy from which it will be hard or impossible to withdraw. They seem at the present moment to be more disposed for a full and free discussion, in the hope that when schemes have been scrutinised, alternatives sifted, and opinions matured, concurrence of belief may issue in unanimous action. They are not anxious for precipitate or impracticable steps to be taken, which, injuring the real interests of either party, may cause a harmful reaction; but they are naturally and rightly desirous that the most complete and candid consideration should be accorded to serious and legitimate aspirations. It may therefore be assumed that, while on the one hand a fresh discussion in the immediate future of the question of Free Trade and Protection cannot be avoided by any dogmatic declaration that the controversy was settled in the middle of the last century, on the other hand occasion will be supplied for the cconomist to contribute his quota without fear or favour to the reopened debate before a definitive conclusion is reached.

That the debate would have been reopened without the special poweriul influence of the encouragement of Colonial trade as a means to that closer union of the British Empire, which has presented itself as at once more immediately possible and more urgently necessary in consequence of the assistance of the Colonies in the African War, is difficult to deny. It may be easy for so doughty a Free Trader, and so practised a controversialist, as Sir Robert Giffen to separate in his own mind, and to demonstrate that his opponents are densely stupid or wilfully perverse if they do not follow his example in drawing the distinction, between any question of Free Trade and Protection and the enlargement of the basis of English taxation or the maintenance of our mercantile marine. He may be perfectly accurate in arguing that the taxation of commodities (whether they be imports or not) for purposes of revenue is different from taxation imposed with the object of protection; and it was a shrewd observation of Bonamy Price that the best and most satisfactory definition of Free Trade was that it was the "contradiction" of 
Protection. For Free Trade does not necessarily imply-though Adam Smith's teaching gave countenance to the belief-theabsence of all governmental interference with industry. Nor does it coincide with the entire removal, urged by the advocates of a "free breakfast table," of duties on commodities or even on imports. But it is, strictly and properly defined, the contrary of Protection. It maintains that no discrimination should be made between commodities in the matter of taxation on the ground of their origin, that goods produced at home and abroad, by our colonies or by foreign countries, should be treated alike, and that trade should be allowed to flow in natural channels, unhindered and unaided by fiscal action. It excludes, in fact, discrimination or differential dealing; and taxation of commodities, even of imports, for revenue purposes, if it meets that condition, is consistent with Free Trade thus defined.

It is possible to go further than this; and, departing from the letter, to claim conformity with the spirit, of Free Trade. On such grounds it may be contended that the problematic, or actual, protective influence of a small registration duty, like that upon corn, may be treated as a " negligible quantity," and was so disregarded by statesmen of the unimpeachable probity of Peel and Gladstone. A further advance is capable of support; and Sir Robert Giffen may argue that he is only following in the footsteps of Adam Smith himself, who approved of the Navigation Laws because "defence" was of " much more importance than opulence," when he expresses his willingness, or even anxiety, in the interests of the preservation of British shipping in British hands, to see some revival of the spirit, if not of the letter, of those very laws.

But in all these three instances-and especially in the case of the latter two-it must be remembered that the general public forms its judgments, and reaches its conclusions, in a more rough and ready manner than the economist or the statistician, and can hardly be expected to appreciate or observe these nice refinements of exact distinction. Although Adam Smith himself recognised important exceptions to the " natural liberty," which he was anxious to substitute for the multitudinous and vexatious regulations of his day, it is not unjust or inaccurate to describe him as animated by a "passion" for freedom; and he regarded Free Trade as an integral portion of a general policy of liberating industry from governmental interference. His successors may have attained a more exact analysis than that at which he himself arrived; and a writer, like the late Duke of Argyll, may 
be giving expression to a more profound, and not less consistent, philosophy, when he declares that during the nineteenth century "two great discoveries" have "been made in the Science of Government," of which the "one" is "the immense advantage of abolishing restrictions upon Trade" and the "other" is "the absolute necessity of imposing restrictions upon Labour." But, if actual experience has shown the practical advantage, it requires more than a popular intelligence to appreciate the scientific logic, of this distinction; and Lord Goschen was justified in the House of Lords, when recently discussing the Corn Tax, in arguing that many, if not most, of the original advocates of Free Trade regarded it as but one article in a general creed, which mistrusted the interference of the State with the action of the individual, and that the fiscal reforms, which they supported, were carried into effect at a time when the Legislature was less disposed than it now is to regulate the conduct of industry in the interests of the permanent welfare of the people.

The separation of taxation of imported commodities for purposes of revenue from taxation for purposes of protection is even less easy for the plain man to make, although it rests on a clearer distinction in theory. Nor are the difficulties of securing that strict avoidance of discrimination between commodities of different origin, which is demanded by Free Trade principles, among the least considerable attending actual fiscal practice. To allow trade to flow, according to the Free Trade ideal, in the natural channels of its own unhindered and unaided selection, an excise duty of precise equivalence should be imposed on commodities produced at home, which come into competition with the foreign articles on which a customs duty is levied for purposes of revenue; but the practical statesman has to be content with a rough approximation to this standard, which may be adequate to satisfy the conditions of theory and practice, but may be easily misrepresented by a skilful advocate, or misunderstood by an ill-informed unintelligent observer. To make the further distinction between the quantity of protection, which can, and that which cannot, be neglected, requires the exceptional ability, and the practised skill, of an expert handler of figures, who knows the relative value of quantities: and he may go astray. It is irrational to expect the average citizen to possess or exhibit this quality; and, when he is taken beyond this position, and asked to distinguish between the revival of important provisions of the Navigation Laws and the Protective policy, 
of which they historically formed a part, he may well take refuge in the plea that he is not competent to make the distinction. He cannot grasp, or retain, these nice refinements of theory. A broad and obvious difference will carry conviction; what is complicated and indistinct will confuse and perplex.

A candid study of history indeed will show that the original introduction of a Free Trade policy was due, not so much to any clear or full recognition by the plain man of the logical conclusions of economic reasoning, as to a lively appreciation of the hindrance to the smooth and rapid transaction of business which was caused by the cumbrous regulations of a complicated tariff; and that the repeal of the Corn Laws themselves was the product of the famine in Ireland, and of the enlightened selfishness of manufacturers anxious for cheap labour, no less largely than of the persuasive argument of Cobden and the moving eloquence of Bright. It was the logic of facts rather than the logic of reasoning which converted the man in the street; and it is a natural consequence that an opinion formed under one set of circumstances should be modified, or even transformed, by a change in the relative pressure of facts. That financial exigency, occasioned not merely by the increase, both extraordinary and normal, of our military and naval expenditure, but also by the constant multiplication of demands on the public purse, both central and local, for various objects of civil activity, should suggest, or compel, a resort to new or revived taxes on exports or imports, is a sign of the times in which we live. An export duty on coal, and an import duty on sugar, have been followed by the reimposition of a registration duty upon corn, and the possibility of some protective influence has been attributed, even by supporters of the tax, to the last of these measures. When a Chancellor of the Exchequer is looking for new sources of revenue in order to meet a growing expenditure, the question of some departure from a fiscal policy of free trade is more likely to be raised, if not to be entertained, than when he is engaged in the easier popular task of selecting between the taxes which he will reduce or remit. We no longer dwell in that halcyon epoch, when the revenue was advancing by leaps and by bounds, and peace, retrenchment, and reform were the motto of the day, and the watchword of the party in power.

We also now live at a time when the pressure of trading competition on the part of foreign nations is growing yearly more and more intense. The commercial and industrial supremacy of this country, once undisputed, is threatened by 
the painstaking German and the acute, alert, inventive American. It would have been almost miraculous, if these circumstances had not begotten an increasing disposition to question the wisdom of the fiscal policy pursued by this country, and not followed by the two nations whose rivalry is now most menacing. It is natural that a belief should spread that Englishmen may be compelled to fight Teutons and Yankees with weapons taken from a Protectionist armoury. This inclination of public opinion, whether it be mistaken or not, which seems to point the direction in which a needy finance minister may turn for popular taxation, has lately received the powerful stimulus of a desire to meet the expressed wishes of the official representatives of our leading Colonies for a fuller recognition of a larger partnership in reciprocal trade, It is then no weak or fortuitous combination of circumstances which is conspiring to reopen the question.

The economist advances no idle or presumptuous claim when he asks for a hearing on such a question; for it raises important economic issues, if other considerations less strictly economic cannot be excluded. But, if his advice is to be candid and his counsel opportune, he must banish both fear and favour. $\mathrm{He}$ must not, from any timid scruple, allow himself to be frightened by the suggestion that he is placing himself in evil company, if he sees blemishes in free trade and merits in protection, Nor must he, from any misguided cowardice, shrink from the suspicion of "economic pedantry," if he is convinced that certain "old shibboleths" contain truth which cannot be ignored without danger to national welfare. It may frankly be stated that much modern Protectionist reasoning reproduces some of those ancient fallacies of the Mercantile System, which Adam Smith set himself to refute and explode. Vulgar delusions about money, and the rôle which it occupies in the business of exchange, implying that foreigners, willing to sell us their goods, are un= willing to receive payment in ours, in subtle disguise, or obvious effrontery, reappear in contemporary discussion. The possibility that trade may be circular, and that the figures of the immediate commercial transactions of two countries with one another may be an inadequate representation of their complete trading relations, in consequence of complementary business conducted through the indirect channel of some other country or countries, seems to escape recognition with no less ease and frequency than completeness. The significance of the "invisible exports" of our shipping and carrying business, for which payment must be 
made in an increase of imports, is often neglected or forgotten; and the meaning of the investment of capital abroad, and of interest owing and yielded in return, is disregarded or misread. Statistics of exports and imports, in fact, demand for their full and correct interpretation an amount of economic knowledge, which is not seldom lacking; and they lend themselves, sometimes to error of the gross and popular kind, and sometimes to fallacy as dangerous as it is elusive. But truth must be a feeble plant, when it has to be jealously preserved from the least contagion with error ; and Free Trade does not become absolute unimpeachable verity because its opponents are sometimes guilty of foolish ignorance or perverse absurdity. Nor is it a conclusive reason against any departure from its principles that such a movement should be misinterpreted as countenancing mistakes which Adam Smith corrected.

Adam Smith himself is now regarded by historians as having exaggerated, or misrepresented, Mercantilist opinions which he assailed; and a naked application of his argument to the facts of the present day, without regard to change in surrounding circumstances, would be to repeat the injustice which he committed. Much that he urged belongs to the rare class of abiding verities, and many fallacies, which he denounced, have reappeared. The fact that imports must be paid for by exports may be fairly described as demonstrable truth, although it should be remembered that the time of ultimate payment may be deferred, that money may form some portion, generally small in comparison with other commodities, both of imports and exports, and that a preponderance of imports over exports may as conceivably mark and accompany a withdrawal of capital invested abroad as a payment of interest or a reward for the carriage of goods. But this important truth is often obscured by mistakes about money common to old Mercantilists and modern Protectionists; and Adam Smith rendered a lasting service by laying emphasis upon it.

His appeal again to "natural liberty" as preferable to governmental regulation in matters of trade can hardly fail to maintain its pertinence in all times and at all places, because it requires a combination of wisdom and purity, which officials can rarely, if ever, command, to guide continuously the course of trade in channels, which will lead directly to the maximum advantage of the whole community. In actual practice, a protective tariff is generally both cumbrous and complex, and occasions injury and disturbance to trade, In actual practice, a 
government, being merely human, has rarely the discretion to select the proper industries to encourage, and even more seldom the bravery to prescribe the right amount of assistance which they should receive. The protection of " infant industries," which has been countenanced in theory by orthodox Free Traders, has shown itself in practice open to these objections, and the neutrality of governments in matters of trade is no small security against enfeebling corruption or endangering error. But it should still be remembered that the adoption, or preservation, of neutrality can be seized as an excuse for avoiding an unpleasant but just responsibility, and that the reasons, by which such a policy commends itself to a government, do not necessarily coincide with those which have regard to the interest of the general public. It may be the easiest and least dangerous, it may not be the wisest or most advantageous, policy to follow. In actual fact, perfect neutrality is hard, if not impossible, to attain. As we saw previously, free trade strictly requires that for every customs duty on an import from abroad an equivalent excise duty should be imposed on the commodity produced at home with which it competes. If trade is to flow in its natural channels, no particle of assistance should be given, and no atom of hindrance should be offered, to particular industries. But beside the question of the precise equivalence of customs and excise, it is not easy, especially in these days of increased governmental interference, to avoid according some preference, or imposing some disability, by governmental action, whether fiscal or other, which will exert a special effect on some particular trade or trader. ${ }^{1}$ Neutrality then may, on occasion, be wrong; it is rarely, if ever, fully attained.

Adam Smith is sometimes reproached, and sometimes admired, for being "cosmopolitan." He was certainly what we should describe as an "individualist." But it can scarcely be denied that neither of these positions give now unqualified satisfaction. They conflict rather than accord with prevailing tendencies.

It is true that Adam Smith, assailing the " mean and malignant" devices of the Mercantile System, honestly thought that freedom of trade would redound to the advantage of his country. It is no less true that Peel and Cobden were convinced that the most effective weapons, with which England could meet the hostile tariffs of foreign nations, would be discovered in the

1 The Agricultural Rating Act for example, might be represented as operating as a bounty to agriculture. 
removal from herself of the disabling restriotions of duties upon imports. But, on the other hand, there oan be no doubt that the Free Trade Reformers of the middle of the nineteenth century confidently thought that the example set by their country would be followed by others, and that they regarded good-will and peace between nations as the natural necessary consequence of international trade. For a time some of their hopes promised to be realised, and during the third quarter of the century a distinct movement was evident in the direction which they expected; but in the next twenty-five years the current was altered, and a general revival of Protection in foreign countries thrust Free Trade into the background. Whether or not the most powerful force prompting this policy was the wish to provide by popular indirect means the revenue required to maintain increased armaments, there can be little doubt that a keen "national" spirit has attended the formation of those vast armies, embracing nearly the whole of the male population of a country, which are characteristic of our day, and is a far more potent force directing the conduct, and forming the attitude, of peoples than any cosmopolitan feeling. It is equally certain that such a spirit encourages, and is encouraged by, the commercial rivalry, which is also a characteristic of our day. But this " national" feeling will be allowed by the candid observer to harmonise more evidently with the ideas of the Mercantile System than with those of Free Trade. The Mercantile System aimed at the maintenance and increase of national power, and the attention which it paid to the accumulation of treasure, to the development of shipping, and to the encouragement of agriculture as a stimulus to a vigorous population, was prompted by this ruling motive. Free Trade, on the contrary, was based on the novel conception, to which Sir Dudley North first gave emphatic and striking expression, that in matters of trade the whole world was to be as one nation, and nations were to be as persons. A most powerful argument urged by Adam Smith was the assertion that the advantages of the division of labour between individuals in a country might be extended by analogous reasoning to nations engaged in international commerce, and Colonel Torrens bestowed on Free Trade the significant title of "territorial division of labour." The most famous, and perhaps the most influential, critic of the teaching of Adam Smith, Friedrich List, called his book the "National System of Political Economy," and List has been justly styled the immediate creator of the German Zollverein, and, indirectly, through the medium of Carey, was the 
inspirer of Protection in the United States of America. With certain qualifications, it is neither inaccurate nor misleading to say that Free Trade is "cosmopolitan" and Protection is "national."

The extension by Adam Smith of the analogy of the division of labour to international trade was marked by his accustomed skill of argument and apt fertility of illustration; and he enforced with admirable and convincing power considerations which his opponents were prone to overlook. Division of labour permits nations, as it allows individuals, to concentrate their attention on work for which they possess the greatest capacity, and enjoy the best opportunity. Both parties to an exchange may derive advantage from the special continued use by either of their peculiar ability or fortune; and they may sustain loss from restrictions, which compel them to engage in occupations for which they are less completely fitted. But the gain and the loss, it must be remembered, though real and often considerable, are, in the last analysis, the consequence of an increase or diminution in the total amount of wealth produced. Concentration on particular work, if pushed to an extreme, may result in benefit to the community at the expense of injury to the individual ; and capacity and opportunity may be the acquired outcome of artificial influence or intentional training as well as the regular product of natural or inherited diversity. The world, as a whole, undoubtedly gains through the establishment of Free Trade, and the different nations participate in that gain. But it is conceivable that they may secure the result by risking or sacrificing some essential or desirable elements of national life, which do not necessarily tend to promote the very same objects as those sought and attained in the promotion of international trade. It is conceivable that national development, guided by cosmopolitan considerations, may remain imperfect or become incomplete. Some capacities may fail to reach independent maturity for lack of defence or encouragement in the period of immature infancy. Others may be doomed to unmerited and unfortunate destruction because, though nationally useful, they are not internationally indispensable. A complete theory of the matter must take such possibilities into account, although in practice it may be argued that they are not of sufficient importance to outweigh the advantages against which they are set, or the disadvantages by which they are accompanied. Yet the protection of infant industries has received the support of orthodox free traders; and the maxim that "defence" is of "much more importance than 
opulence" is capable of a wider application than that bestowed by its author. Economic considerations are not the only motives which do as a matter of fact, or should as a matter of principle, direct the policy of nations, and Free Trade is exceeding its province when it assumes a monopoly of economic, or still more, of other national, virtues. Certainly the modem prominence of national aims, and the wide prevalence of a keen national spirit, are calculated to qualify the extreme rigour of Free Trade doctrine advanced and defended on cosmopolitan grounds. And, if both parties may derive advantage from a bargain, and the gain of one does not imply the loss of the other, the same modern economic theory, which has emphasised and elucidated this possibility, has shown that a nation may conceivably, by fiscal operations, influence the course of international trade, and the settlement of international bargains, to its own advantage and the disadvantage of its rival. It has supplied a fresh consideration of which account must be taken by the enlightened selfishness of nations.

The Mercantile System, avowedly adopting a narrower ideal than that afterwards espoused by Free Trade, sought the promotion of the power of a nation at the cost, if necessary, of the destruction or loss of its rivals; but it nevertheless marked an advance on the economic policy to which it succeeded. It substituted central for local regulation; it aimed at the interests of a nation as a whole and not at those of a particular district or an individual city. Free Trade, on the other hand, was cosmopolitan; it was also individualistic. Its conception of industry was that of individuals contending with one another, seeking under the influence of free competition the occupation for which they were best fitted, and exchanging their products without aid or hindrance from the State to which they belonged. But, in the present day, not merely has the idea of State regulation grown in importance and in popularity, in some cases at the expense, according to other schemes of philosophy, as a necessary means of enabling the realisation, of individual liberty ; but combination has steadily encroached on the field where competition was once dominant. Economists for some time have recognised a rôle, not necessarily injurious or futile, which trade unions may assume in the settlement of wages; and the consideration of the conditions and effects of monopoly of supply, or of demand-of sellers or of buyers-has claimed a chapter, or sections of a chapter, in more recent discussions of economic theory. At the actual moment the presence and growth of Trusts, controlling, or seeking to control, a large part, if not the whole, of particular industries, 
has excited great interest, and awakened no little alarm ; and they are recognised, however much they are distrusted, as an abiding phenomenon of American trade and a menacing portent in European business. It is indeed affirmed, not without reason, that the Protectionist tariff of the United States, which shields certain industries from foreign competition, fosters the growth of monopolies, which would not, and could not, flourish under Free Trade. But it is easy to push this argument beyond its legitimate bounds, and it must be noted that Trusts claim to succeed because they effect certain economies in production, which smaller organisations cannot achieve. That there is some waste in free competition may be said to be established by the discussion on the causes and effects of Trusts, which economic writers have recently conducted; and it is possible, and not illegitimate, to reverse the reasoning, and to argue that the increasing prominence of combinations, of which Trusts are one conspicuous example; suggests some revision of that assumption of competition between individuals, on which Free Trade, together with the scheme of economic theory, with which it is linked, is, in the last analysis, based.

For these reasons, then, it may be urged that the case for Free Trade requires to be stated afresh, that the question was not settled by the discussions of the middle of the last century, and that no answer will meet the demands of the new situation, which refuses to take into account the fresh circumstances that have arisen. A dogmatic appeal to the conclusions of an ancient debate may be seized by those who do not wish, or care, to re-examine their faith in the light of indisputable, if awkward or unfamiliar, facts. An authoritative declaration, unsupported by reasons, may command the acquiescence of lazy or negligent observers content to have their opinions formed for them by others. A peremptory rejection of proposals, which commend themselves for their intrinsic importance, but involve a risk of contagion with vulgar or plausible error, may suit that discretion which is the better part of valour. But it seems improbable that by means like these the economist will succeed in obtaining a hearing, and exerting an influence, in the settlement of the question.now at issue. He must reckon with the strength of national aspirations, and he must deal with those new phenomena, of which Trusts are a representative type. National interests and aims may easily conflict with cosmopolitan ideals. The requirements of the self-sufficiency of a nation may seem to demand a departure from Free Trade in order to encourage 
particular industries of national importance. The claims of political advantage may outweigh pure economic considerations. An immediate economic loss may be chosen as a less serious sacrifice than future injury, whether economic or political, threatened or assured, to national existence or welfare. These are circumstances, of which some are economic, and others belong to connected regions of inquiry, which the economist must bear in mind when he investigates the new application of the theory of Free Trade to that modern business world, where monopoly and combination seem to be encroaching with steady but sure advance on the sphere of individual competition.

But, if dogmatism be inopportune, honest counsel and expert advice are needed, if they are not welcome. These the economist is able to supply. It is his mission to see further and deeper than the average citizen into the phenomena of trade and industry. It is his duty to discern and disclose the forces at work beneath the surface of things, to recall to the minds of men considerations which they might overlook, to compel them to take into account circumstances which they may of themselves fail to notice. If economic loss is to be risked, the risk should be run deliberately and not unknowingly. If an immediate sacrifice is to be incurred to secure future advantage, both the sacrifice and the advantage should be clearly discerned and accurately gauged. The danger in all such discussions, as Bastiat urged long ago, is that the "seen" should prevent men from discovering and examining the "unseen." It is the task, as it is the privilege, of economics, to reveal and exhibit the " unseen."

Of the natural tendency to attach undue exclusive importance to the obvious and the superficial the Protectionist has been more frequently guilty than the Free Trader. The direct advantage, which enures from Protection to protected trades, can be observed without difficulty. "What I wish," M. Thiers is quoted by Bagehot as saying, "is to see the tall smoking chimneys" of my protected manufactures. The indirect injury occasioned to the consumer, in the higher price or the inferior quality of the goods he is forced by Protection to buy, escapes notice because it can only be realised by a process of reasoning. By such a process alone it is possible also to appraise the effect on the manufacturer, whether he himself enjoy the advantage of protection or not for his products, of the higher price or inferior quality of the raw material he is compelled by an import duty levied upon it, when coming from abroad, to meet. And the negative consequenees of Protection in withdrawing a 
stimulus to enterprise and resource, in checking the discovery and application of new machinery and inventions, or the adoption of improved methods of organisation of business, can only be measured by those, who are acute or informed enough to look. beyond the immediate present, and to penetrate below the actual surface. In all these cases the economist is able to see and disclose what the plain citizen is not competent or accustomed to note.

It is sometimes said that Free Trade pays an excessive regard to the consumer, and Protection to the producer; and the contention is true, so far as they approach the consideration of the problem from two different sides, although the bracing effects of free competition, noted before, must not be neglected. Competition, however, may crush and destroy as well as stimulate and improve; and judicious Protection may conceivably encourage without enervating, and create without enfeebling. When it is argued, with no little force, that the interests of the consumer, because they are remote and indirect, are more apt to be overlooked than those of the producer, which are immediately obvious, the argument may be frankly admitted. But the further contention that consumers are a more numerous body than producers, and that producers themselves are often consumers, for example, of raw material, must be considered beside, and not apart from, the circumstance that consumers are similarly in many cases producers, and that it is one of the errors most commonly occasioned by the necessary limits of economic analysis to forget that processes distinguished in text=books are simultaneous in time, and classes, separated by economists from one another, consist largely of identical individuals. The interests, like the persons, of consumers and producers may be artificially parted, but in the nature of things they are connected. The misapprehension arising from this unreal division is shared by Free Traders and Protectionists.

L. L. Price 